\title{
Russia protests at US science sanctions
}

[MOsCow] Russian officials have criticized the US decision to impose sanctions against 10 Russian institutions - including three prominent scientific centres - for alleged collaboration with Iran that could aid the development of nuclear missiles.

The three research bodies are the 'Mendeleyev' Chemical Technological University (CTU), the Moscow Institute of Aviation (MAI) and the Energy Technical Scientific Research Institute (ETSRI).

Russian prime minister Yevgeny Primakov described the measures as "counter-productive for relations between Russia and the United States, which are of great value to us".

Vladimir Rachmanin, a spokesman for the Ministry of Foreign Affairs, has dismissed US accusations as "groundless" adding that the sanctions "will not go unanswered".

The scientific institutions were identified by Samuel Berger, National Security Advisor to President Bill Clinton's administration, as having broken the nuclear non-proliferation treaty. But Igor Sergeev, Russia's defence minister, says they could not have broken the treaty "because they did not possess full knowledge of [nuclear and launcher] technologies".

Last July, after Iran launched its own rocket, the United States introduced sanctions against seven Russian companies and universities on the grounds that they had supplied Iran, Libya and North Korea with nuclear and rocket technology, materials and equipment of dual — civilian and military — use.

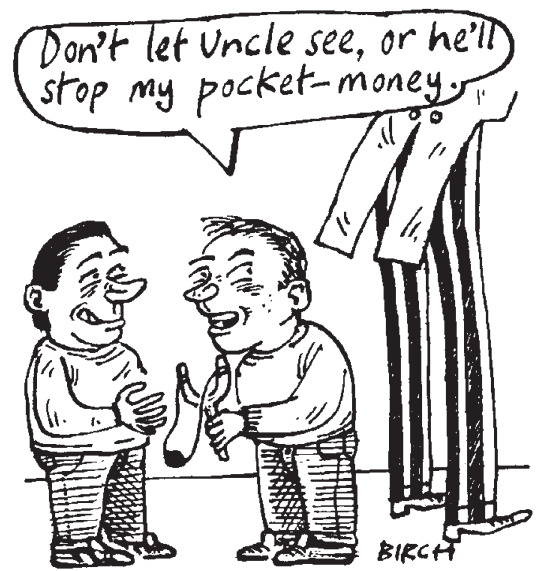

The Russian reaction was relatively mild. The Federal Security Service (FSS) admitted that a few Iranian companies with links to the launcher programme had been operating in Russia, but were no longer doing so.

It was said that the Iranians had tried to order a component of a liquid-type jet engine from the Russian company Trud, claiming it was for pumping gas. According to the FSS, "this attempt was revealed at an early stage and immediately stopped".

Now, however, the FSS says it has failed to find any evidence of dealing in secret documents at the three scientific organizations added to the US blacklist. The institutions deny all the accusations.

Pavel Sarkisov, rector of the CTU, calls the US accusations "absurd". He says: "We have

\section{Los Alamos secrets 'were leaked to China'}

[WASHINGTON] A major security breach involving a Chinese-American computer scientist working at the Los Alamos nuclear weapons laboratory in New Mexico has enabled China to copy the United States' most important recent nuclear warhead, according to congressional investigators and Department of Energy officials.

The New York Times reported last weekend that the scientist failed a polygraph test last month and has been moved from nuclear weapons work, but not charged with any offence. The scientist, Wen Ho Lee, fell under suspicion in 1997, but was allowed to remain in a sensitive position at the laboratory while an $\mathrm{FBI}$ investigation continued.
On Monday (8 March) the energy department announced that he had been dismissed.

Some department officials and investigators from the Intelligence Committee of the House of Representatives believe that the alleged espionage enabled China to develop and test a warhead similar to the W88, the compact nuclear warhead used in the US Trident II submarines. Data from Chinese weapons tests led US officials to suspect espionage at Los Alamos, where FBI investigations focused on one suspect.

But other intelligence officials have questioned the importance of the alleged espionage. They argue that China could have developed a warhead with similar characteristics to the W88 by itself, or with information from Russia. China has already denied that espionage took place.

In a statement this week, Edward Curran, head of counter-intelligence at the energy department, said that "the extent to which these disclosures may have helped part of the Chinese weapons programme is unclear". But he confirmed that steps had been taken to increase security.

The allegations will further intensify pressure to tighten security at the national laboratories. After criticism from Congress, the laboratories have restored full checks on visitors from certain countries (see Nature 395, 627; 1998). Colin Macilwain only one Iranian postgraduate, who is preparing a dissertation on polystyrene synthesis [which] has nothing to do with nuclear research - it is used in the building industry, and engineering." Sarkisov says the sanctions will have no effect on the CTU, as it has no contracts with the United States.

But the CTU has a prominent research programme in nuclear-waste reprocessing. According to the ecologist Alexei Yablokov, former adviser to President Boris Yeltsin on nature conservation and public health, "CTU is engaged in developing the chemical component for the rocket fuel".

This could explain the Clinton administration's measures, described in a statement as intended "to cease the transfer of sensitive Russian technology to Iran”.

Alexander Matvienko, rector of the MAI, admits that 28 Iranians are studying at his university. But he insists that they have no access to secret materials.

US concern seems to stem from the MAI's collaborative research agreement with Iran. The university will be badly hit by the sanctions, as it has contracts worth $\$ 500$ million with US companies, while its staff — like those at the CTU - will no longer be able to make US lecture tours.

ETSRI is one of the leading institutes of the atomic energy ministry, and ministry head Oleg Adamov was ETSRI's director for more than a decade. "We are much more concerned than the United States with the possibility that Iran could have nuclear weapons and the rockets to deliver them, as Iran is our neighbour; only the Caspian sea divides us," he says. "We are therefore being very cautious not to promote Iran's rocket and nuclear weapons programmes.”

Last spring, at a meeting with Reza Agkhazadeh, Iranian vice-president and president of the Iranian organization for atomic energy, Adamov said that "all co-operation with Iran in nuclear technologies is within the frame of the non-proliferation treaty, and in accordance with the dual technologies list".

ETSRI will be worst hit by the sanctions. It has received many grants from the International Scientific Technical Centre set up with US help to dissuade Russian scientists with knowledge of 'sensitive technologies' from leaving the country to join 'unstable regimes'. The loss of this money could be more significant than the $\$ 800$ million contract that Adamov signed with Iran for the construction of an atomic power station.

The United States has also threatened to freeze its contacts with Russian space programmes if Russia does not stop supplying Iran with rocket technology. As a result, the Russian space agency might not receive the $\$ 1$ billion it is expecting for launching US satellites with its Proton rocket. CarlLevitin 